\title{
Positive mass balance during the late 20th century on Austfonna, Svalbard, revealed using satellite radar interferometry
}

\author{
Suzanne BEVAN, ${ }^{1}$ Adrian LUCKMAN, ${ }^{1}$ Tavi MURRAY, ${ }^{1}$ Helena SYKES, ${ }^{1}$ Jack KOHLER ${ }^{2}$ \\ ${ }^{1}$ Glaciology Group, School of the Environment and Society, University of Wales Swansea, Singleton Park, \\ Swansea SA2 8PP, UK \\ E-mail: 301074@swansea.ac.uk \\ ${ }^{2}$ Norwegian Polar Institute, Polar Environmental Centre, NO-9296 Tromsø, Norway
}

\begin{abstract}
Determining whether increasing temperature or precipitation will dominate the cryospheric response to climate change is key to forecasting future sea-level rise. The volume of ice contained in the ice caps and glaciers of the Arctic archipelago of Svalbard is small compared with that of the Greenland or Antarctic ice sheets, but is likely to be affected much more rapidly in the short term by climate change. This study investigates the mass balance of Austfonna, Svalbard's largest ice cap. Equilibrium-line fluxes for the whole ice cap, and for individual drainage basins, were estimated by combining surface velocities measured using satellite radar interferometry with ice thicknesses derived from radio-echo sounding. These fluxes were compared with balance fluxes to reveal that during the 1990s the total mass balance of the accumulation zone was $(5.6 \pm 2.0) \times 10^{8} \mathrm{~m}^{3} \mathrm{a}^{-1}$. Three basins in the quiescent phase of their surge cycles contributed $75 \%$ of this accumulation. The remaining volume may be attributable either to as yet unidentified surge-type glaciers, or to increased precipitation. This result emphasizes the importance of considering the surge dynamics of glaciers when attempting to draw any conclusions on climate change based on snapshot observations of the cryosphere.
\end{abstract}

\section{INTRODUCTION}

Recent changes in atmospheric circulation have resulted in a $0.5^{\circ} \mathrm{C}_{\text {decade }}^{-1}$ increase in the recorded annual mean air temperature at Longyearbyen on Spitsbergen, western Svalbard, and a precipitation increase of $1.7 \%$ decade $^{-1}$ since the late 1960s (Førland and Hanssen-Bauer, 2002). These data are supported by ice-core analyses from the ice cap Lomonosovfonna, the highest ice field on Spitsbergen, which indicated an accumulation rate increase of $25 \%$ over the latter half of the 20th century compared with the years 1715-1950 (Pohjola and others, 2002).

Observations suggest that most low-altitude Arctic glaciers have been retreating since the 1920s, but with no significant increase in melting over the last 40 years (McCarthy and others, 2001). On Svalbard, ice masses are known to have generally retreated since the Holocene (Hagen and Liestøl, 1990). However, the present-day mass balance of the majority of Svalbard's ice caps and glaciers is poorly defined, so the contemporary response to recent climate change is difficult to assess. In situ mass-balance observations are mostly limited to a small number of more easily accessible glaciers in western Spitsbergen. However, the present climate on Svalbard is determined by a balance between two weather regimes: the first characterized by frequent passages of low-pressure systems from the southwest, and the second bringing the snow-bearing cold northeasterly polar winds from the Barents Sea. This zonal climate variation means that mass-balance measurements on Spitsbergen are probably not representative of the climate of ice masses to the east of Svalbard, such as Austfonna $\left(8120 \mathrm{~km}^{2}\right)$ and Vestfonna $\left(2510 \mathrm{~km}^{2}\right)$, the two largest ice caps.

An estimate of the overall net balance of Svalbard ice masses of $-4.5 \mathrm{~km}^{3} \mathrm{a}^{-1}$ has been made by combining net balance altitude gradients for 13 different regions in Svalbard with a digital elevation model (DEM) (Hagen and others,
2003). Austfonna was included in this net balance estimate, and was determined to have a net balance close to zero using a balance ratio chosen to match that of other areas in Svalbard due to the lack of information on ablation rates.

In this study, we estimate the total mass balance for the accumulation zone of Austfonna by calculating the difference between measured and balance fluxes across the equilibrium line. The measured fluxes were the product of remotely sensed surface velocities and radio-echo sounded ice thicknesses. The balance fluxes were based on a specific mass-balance distribution, derived from ice-core data, integrated over the accumulation area. When referring to mass balance, the terminology of Bamber and Payne (2004) is used. This terminology defines specific mass balance to include only the sum of local accumulation and ablation; and local mass balance is used to describe the local mass change of the column. In order to obtain a picture of the spatial distribution of local mass balance, flux differences were apportioned according to drainage basin. Dividing each basin flux difference by the area of its accumulation zone gave a basin-mean local mass balance.

\section{METHODOLOGY AND DATA}

\section{Calculation of balance fluxes}

The balance flux is defined as the rate at which ice must be transported downstream in order for an ice mass to be in equilibrium with the accumulation and ablation rates and hence preserve a stable surface profile. The mean annual balance flux at the equilibrium-line altitude (ELA) for the whole ice cap and for individual drainage basin areas, $S_{\mathrm{C}^{\prime}}$ was calculated by integrating the distribution of mean annual specific mass balance $B_{\mathrm{n}}$ :

$$
F_{\mathrm{b}}=\int_{S_{\mathrm{c}}} B_{\mathrm{n}} \mathrm{d} S
$$




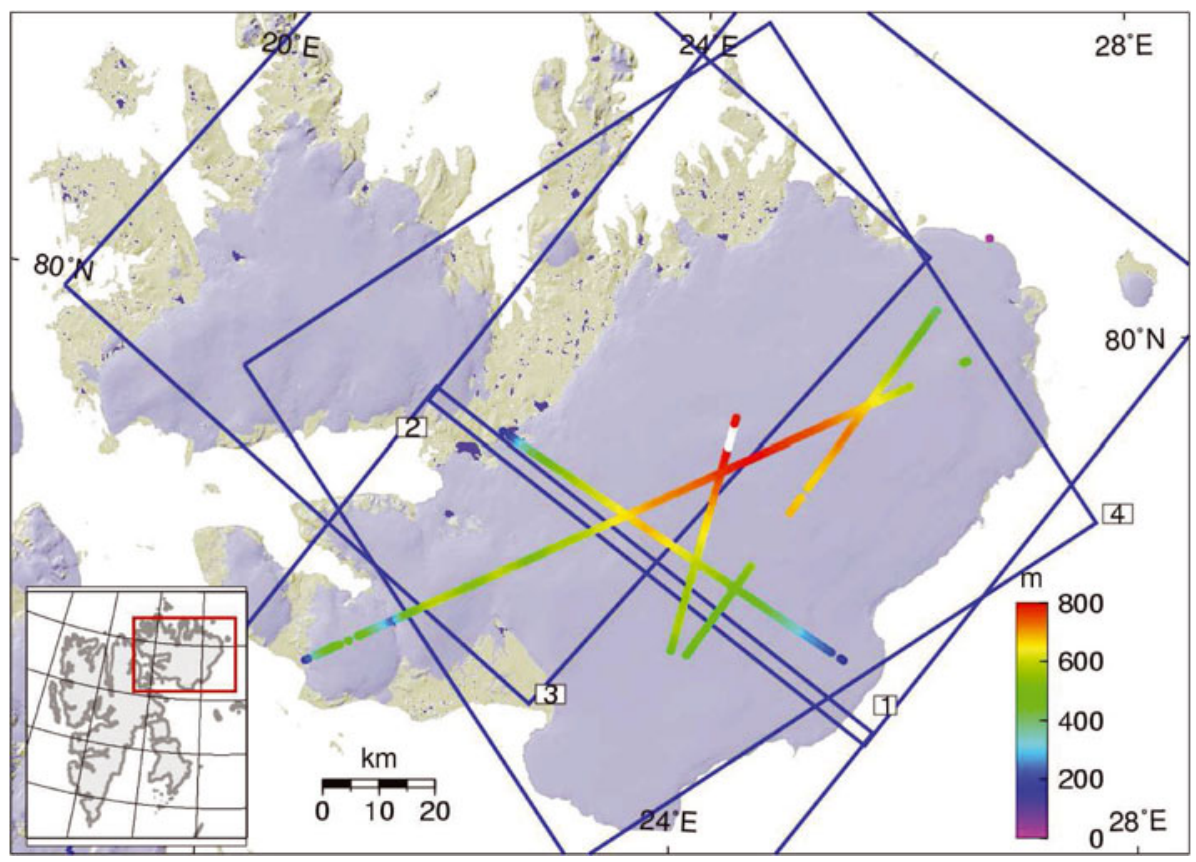

Fig. 1. Airborne laser altimeter data points (personal communication from J. Bamber, 2005), and location of data frames listed in Table 1. Inset shows location of Nordaustlandet within Svalbard.

Drainage basin boundaries were geocoded and digitized from a glacier inventory of Svalbard (Hagen and others, 1993), and are referenced according to the World Glacier Inventory identification system.

The distribution of $B_{\mathrm{n}}$ was based on a set of transects of shallow ice cores drilled in 1998/99 in which the 1986 Chernobyl nuclear accident radioactive reference horizon could be detected (Pinglot and others, 2001). It has been shown that estimates of specific balance based on core data correlate well with direct measurements (Lefauconnier and others, 1994). In order to calculate the $B_{\mathrm{n}}$ distribution, altitude gradients of $B_{\mathrm{n}}$ and estimates of the ELA based on the cores (Pinglot and others, 2001) were extrapolated over a $100 \mathrm{~m}$ resolution grid using the Generic Mapping Tools minimum curvature spline interpolator with a tension of 0.65 . The altitude gradients of $B_{\mathrm{n}}$ were then multiplied by the height above ELA, using elevations from the Norsk

Table 1. Interferogram pairs (see Fig. 1 for locations) used for differential processing

\begin{tabular}{|c|c|c|c|c|}
\hline Frame & Dates & $\begin{array}{l}\Delta T \\
\text { days }\end{array}$ & $\begin{array}{c}\text { Baseline } \\
\text { mid-scene } \\
\text { m }\end{array}$ & $\begin{array}{l}\text { Sensitivity to path } \\
\text { length distortion } \\
\mathrm{m} \mathrm{a}^{-1} \mathrm{~cm}^{-1}\end{array}$ \\
\hline 1 & $\begin{array}{l}\text { 5-6 Mar. } 1996 \\
\text { 9-10 Apr. 1996* }\end{array}$ & $\begin{array}{l}1 \\
1\end{array}$ & $\begin{array}{l}180.9 \\
-32.6\end{array}$ & 3.1 \\
\hline 2 & $\begin{array}{l}\text { 5-6 Mar. } 1996 \\
\text { 9-10 Apr. 1996* }\end{array}$ & $\begin{array}{l}1 \\
1\end{array}$ & $\begin{array}{l}179.2 \\
-36.8\end{array}$ & 3.1 \\
\hline 3 & $\begin{array}{l}\text { 6-9 Jan. } 1994 * \\
\text { 9-12 Jan. } 1994\end{array}$ & $\begin{array}{l}3 \\
3\end{array}$ & $\begin{array}{r}-64.4 \\
80.9\end{array}$ & 0.9 \\
\hline 4 & $\begin{array}{l}\text { 2-5 Mar. 1994* } \\
\text { 14-17 Mar. } 1994\end{array}$ & $\begin{array}{l}3 \\
3\end{array}$ & $\begin{array}{l}-2.8 \\
78.1\end{array}$ & 1.2 \\
\hline
\end{tabular}

Notes: Interferograms used for velocity calculations are indicated by ${ }^{*} . \Delta T$ is the time spanned by the interferogram. Locations of frame numbers are shown in Figure 1.
Polarinstitutt $100 \mathrm{~m}$ resolution DEM. This DEM was used rather than the interferometric heights calculated as part of the surface velocity method, in order to maintain independence between the two flux estimates.

\section{Estimation of downslope velocity}

The procedures for deriving glacier surface velocities using satellite radar interferometry (SRI) are well established (Kwok and Fahnestock, 1996). In this study, differential SRI was carried out on pairs of 3 day ERS-1 (European Remotesensing Satellite) interferograms from 1994 and 1 day ERS-1/ ERS-2 interferograms from 1996 (see Table 1; Fig. 1), using Gamma Remote Sensing software. In brief, pairs of interferograms were differenced to remove the effects of surface displacement on interferometric phase, leaving only topographic phase effects. After appropriate scaling, this topographic phase could be removed from one of the original interferograms. The resulting unwrapped interferograms then provided measurements of surface displacement in the lineof-sight (LOS) direction of the radar, over the period spanned by each interferogram.

Three-dimensional (3-D) surface velocities were derived from these LOS surface displacements by assuming that the ice flows parallel to the surface (Kwok and Fahnestock, 1996) and in the direction of maximum surface slope (Paterson, 1994; Unwin, 1998). The surface elevation used to compute flow directions was generated during the first part of the differential procedure by using a number of ground-control points (GCPs) to create a DEM from the topographic phase. Some GCPs were provided by assigning the coast, as identified on the multilooked synthetic aperture radar (SAR) intensity images, to a height of $0 \mathrm{~m}$ a.s.l. On the ice cap, 650 GCPs were taken from 1996 NASA airborne laser altimetry data (shown in Fig. 1; personal communication from J. Bamber, 2005). In order to determine flow directions, the DEM was not required to be of absolute accuracy. Differences between the effective heights of the 


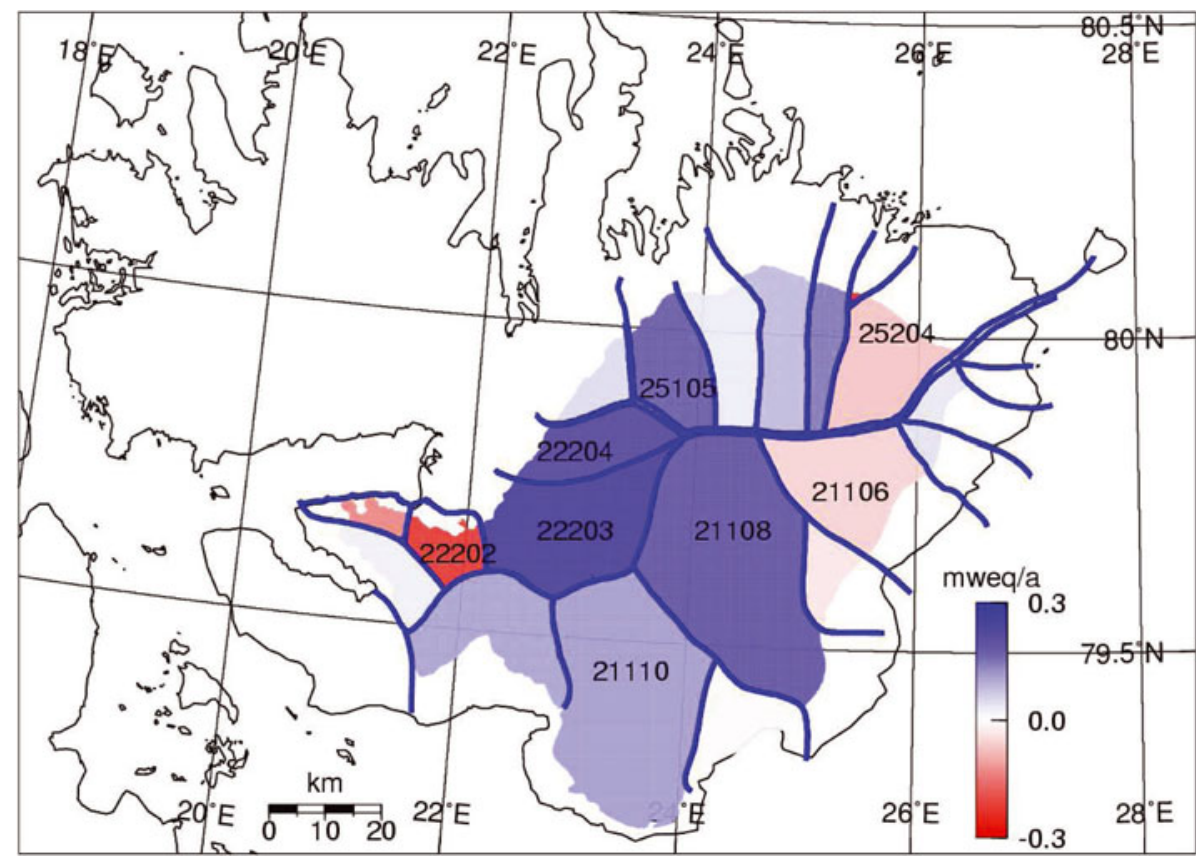

Fig. 2. Basin mean local mass balance. Shown in blue are those basins for which the mean local mass balance was positive, and in red those for which it was negative.

scattering layers between lidar and the C-band radar, which may penetrate up to $9 \pm 2 \mathrm{~m}$ in cold polar firn (Rignot and others, 2001), are therefore not important.

In order to obtain as complete a coverage as possible over the ice cap, a composite of surface velocities was produced by infilling the 1996 results with measurements from 1994. Surface velocities were occasionally retrievable for the same area from more than one interferometric dataset. This overlap enabled us to ascertain that surface velocities had not changed significantly over this period, as changing the order of priority of datasets when producing the composite made no discernible difference to the resulting flux estimates.

The spatial resolution of the SAR data is $\sim 4 \mathrm{~m}$ in the azimuth direction and $\sim 20 \mathrm{~m}$ in the ground-range direction. After multilooking to reduce phase noise and conversion to a geographic coordinate system, the spatial resolution of the 3 -D velocities was $50 \mathrm{~m} \times 50 \mathrm{~m}$. A profile of annual surface displacements in the downslope direction was extracted along the equilibrium line at intervals of $50 \mathrm{~m}$ for use in the flux calculations.

\section{Calculation of measured fluxes}

Measured fluxes in cubic metres of water equivalent per annum $\left(\mathrm{m}^{3}\right.$ w.e. $\left.\mathrm{a}^{-1}\right)$ were computed by multiplying the equilibrium-line profile of annual surface displacements by the product of the extraction interval and the ice thickness at that point, using a factor of 0.84 to allow for the relative density of ice to water (Paterson, 1994).

The ice-thickness distribution was constructed from airborne radio-echo sounding (RES) data collected in 1983 (Dowdeswell and others, 1986), with the additional constraint of ice margins, which may be grounded below sea level, being set to a thickness of $100 \mathrm{~m}$, as it has been observed that the ice is generally at least this thick even at the ice-cap margins (Dowdeswell and others, 1986). The $50 \mathrm{~m}$ wide flux elements along the equilibrium line were then summed for each drainage basin and for the entire accumulation zone.

\section{RESULTS}

\section{Balance fluxes}

Based on the ice-core data, specific mass balances within the accumulation zone of Austfonna reach a maximum of $0.45 \mathrm{mw}$.e. $\mathrm{a}^{-1}$ toward the summit of the ice cap at an altitude of $\sim 800 \mathrm{~m}$. Integrating the specific mass-balance distribution over the $5700 \mathrm{~km}^{2}$ accumulation zone of Austfonna results in an estimated equilibrium-line balance flux of $10.5 \times 10^{8} \mathrm{~m}^{3}$ w.e. $\mathrm{a}^{-1}$. Basin equilibrium-line balance fluxes varied from $1.9 \times 10^{8} \mathrm{~m}^{3}$ w.e. $\mathrm{a}^{-1}$ for basin 21108 , down to $8.0 \times 10^{4} \mathrm{~m}^{3}$ w.e. $\mathrm{a}^{-1}$ for basin 25203 , the variations being due to the altitude and areas of the different catchments (Fig. 2).

\section{Measured velocities and fluxes}

Downslope SRI velocities were obtained over almost all of Austfonna, Vestfonna and the two smaller ice caps to the southwest of Austfonna (Fig. 3). Outlet glaciers with maximum velocities of up to $100-150 \mathrm{~m} \mathrm{a}^{-1}$ can be identified at various points around the ice cap. Ice divides are characterized by low velocities. Austfonna's ELA as extrapolated from the ice-core estimates, and along which the measured velocities and ice thicknesses were extracted, varies from just over $100 \mathrm{~m}$ in the southeast to over $460 \mathrm{~m}$ in the northeast (black contour in Fig. 3). The ice thickness reaches a maximum of $\sim 590 \mathrm{~m}$ toward the centre of the ice cap, and for most of the north and east coasts the ice is grounded below sea level. Along the equilibrium line the ice thickness is $300-400 \mathrm{~m}$ in the north and $\sim 100 \mathrm{~m}$ in the south.

The total measured ELA flux for Austfonna was (4.9 \pm 1.0) $\times 10^{8} \mathrm{~m}^{3}$ w.e. $\mathrm{a}^{-1}$. Breaking the flux down into individual drainage basins, the largest contributions were $1.1 \times$ $10^{8} \mathrm{~m}^{3}$ w.e. $\mathrm{a}^{-1}$ from basin 21106 , and $0.7 \times 10^{8} \mathrm{~m}^{3}$ w.e. $\mathrm{a}^{-1}$ 


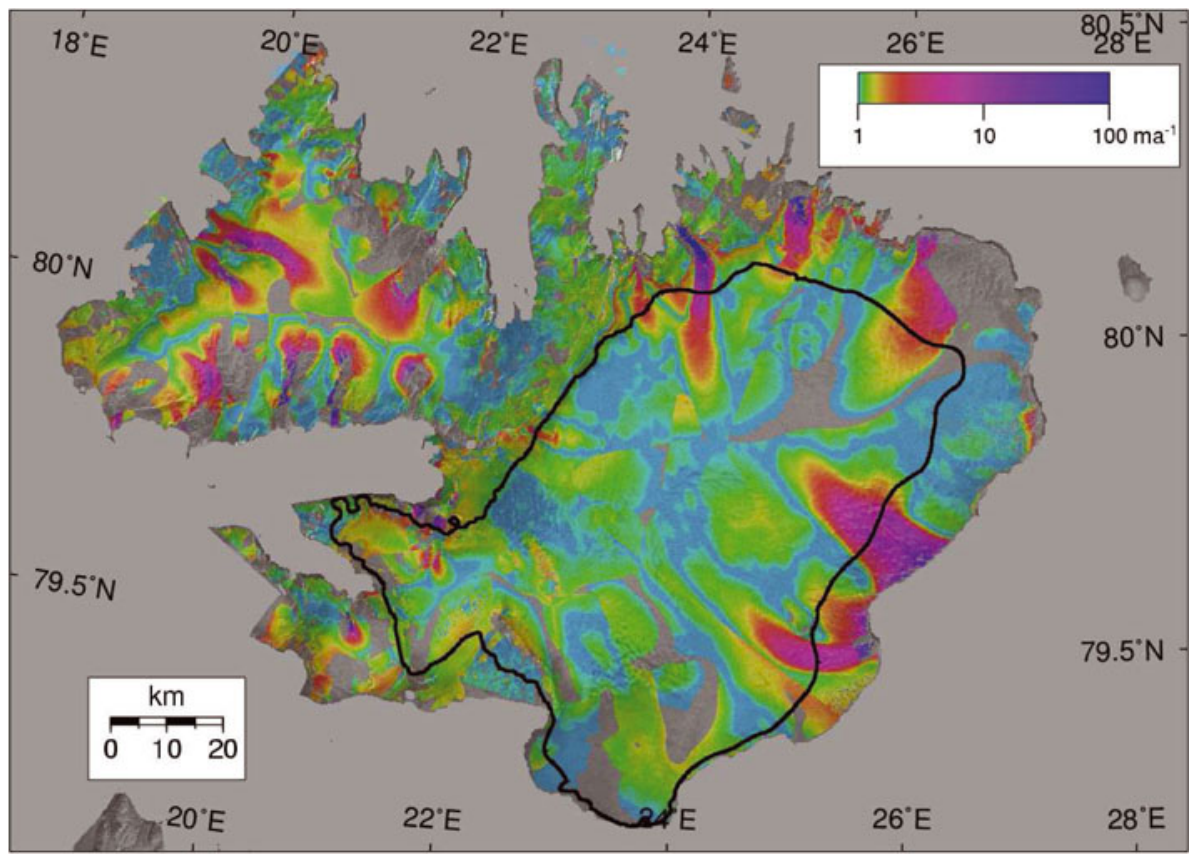

Fig. 3. Composite of downslope interferometric velocities. In grey are regions for which it was not possible to retrieve velocities using the data selected for this study, due to either phase coherence losses or flow-direction restrictions. The black line marks the ELA.

from basins 21108 and 25204, with estimated errors of about $+0.3 \times 10^{8} \mathrm{~m}^{3}$ w.e. $\mathrm{a}^{-1}$.

\section{Mass balance of the ice cap}

The total mass balance of the ice cap, i.e. the difference between the measured and balance fluxes, was found to be of the order of $(5.6 \pm 2.0) \times 10^{8} \mathrm{~m}^{3}$ w.e. $\mathrm{a}^{-1}$. Using the basin boundaries, it was possible to apportion this flux imbalance according to drainage basin. The most positive total mass balance was $1.9 \times 10^{8} \mathrm{~m}^{3}$ w.e. $\mathrm{a}^{-1}$ for basin 21108 , with a further $1.1 \times 10^{8}$ and $1.2 \times 10^{8} \mathrm{~m}^{3}$ w.e. $\mathrm{a}^{-1}$ for basins 21110 and 22203, respectively.

The mean local mass balances, in mw.e. $\mathrm{a}^{-1}$, represent the difference between balance and measured fluxes divided by the area of the accumulation zone for each basin (see Fig. 2). The most positive mean local mass balances found were for basins 22203, 22204 and 21108, with 0.23, 0.20 and $0.18 \mathrm{~m}$ w.e. $\mathrm{a}^{-1}$, respectively. The most negative local mass balance was -0.22 m w.e. $\mathrm{a}^{-1}$ for basin 22202 .

\section{Residence times}

Another parameter derived was the approximate residence time for each drainage basin. The residence time is simply the total volume of ice contained within the accumulation zone of each basin divided by the flux rate at the equilibrium line. Across Austfonna, values range from around 500 years for the smaller glaciers to over 10000 years for the larger slow-flowing glaciers.

\section{DISCUSSION}

The total mass balance of the accumulation zone of Austfonna was found to be $(5.6 \pm 2.0) \times 10^{8} \mathrm{~m}^{3}$ w.e. $\mathrm{a}^{-1}$. This value represents just over half the annual accumulation of the ice cap and would seem to indicate that recent accumulation increases are leading to a steady gain in mass. However, when the spatial distribution of total mass balance over the ice cap is analyzed it becomes obvious that the imbalance between balance and measured fluxes is far from uniform. About $75 \%$ of the positive total mass balance comes from just three basins, 21108, 21110 and 22203, all of which are known to be surge-type glaciers in their quiescent phases.

Basin 21108 was shown to have been in surge in 1992, but to have slowed down by 1994 (Dowdeswell and others, 1999). By 1996 it is shown here to have a mean local mass balance of $0.18 \mathrm{mw} . \mathrm{e} . \mathrm{a}^{-1}$, and thus to be continuing to recover its pre-surge profile. Between 1936 and 1938, basin 21110, Bråsvellbreen, underwent the largest surge known for any ice mass (Drewry and Liestøl, 1985): the $30 \mathrm{~km}$ long ice edge advanced by $2 \mathrm{~km}$; 60 years later it is still accumulating mass. Basin 22203, Etonbreen, also surged in 1938 (Hagen and others, 1993).

The local mass-balance distribution suggests that other basins, notably 22204 (Winsnesbreen) and 25105, may also be accumulating mass prior to a surge. Neither of these basins shows signs of ever having surged, nor have they been identified as surge-type glaciers on the basis of driving stresses (Dowdeswell, 1986) or glacier length and substrate (Jiskoot and others, 2000). Basin 25204, Leighbreen, was identified by Dowdeswell (1986) as possibly being of surge type on the basis of its low driving stresses and surface profile. Measured velocities, deriving from 1994 data, were $<40 \mathrm{~m} \mathrm{a}^{-1}$ at all points on this glacier and showed no acceleration relative to 1992 velocities. Hence, although its local mass balance was negative in 1994, flow rates do not suggest that it was in surge.

In measuring the equilibrium fluxes, this study made two assumptions referred to, but not quantified, in the error analysis. The first was that all of the ice transport was achieved by basal sliding rather than by ice deformation, and the second was that the velocities measured are representative of annual velocities.

It is probable that for some sections of the equilibrium line the first assumption does not hold true, and that the sliding assumption causes the flux to be overestimated by up to $20 \%$ (Paterson, 1994). This overestimate is only likely to 
be the case in areas of low flux, as it has been estimated that for much of Austfonna the maximum flow rate that can be achieved by deformation alone is $5 \mathrm{~m} \mathrm{a}^{-1}$ (Dowdeswell and others, 1999), and it is apparent that at the ELA most surface velocities exceed this. In addition, plumes of sedimentladen basal meltwater have been identified in Landsat images for a number of tidewater-terminating glaciers along the eastern edge of Austfonna, indicating that their bases are at pressure-melting point and hence sliding is likely (Dowdeswell and Drewry,1989). Of the individual basins where a negative total mass balance is indicated, only basin 21106 would be tipped into a positive balance by a basinwide $20 \%$ decrease in flux.

If the second assumption of no seasonal variations in velocity does not hold true, it may be expected to have the opposite effect, i.e. the late-winter or early-spring flux rates measured here might underestimate mean annual flux rates and hence result in an overestimate of total mass balance. In order for the total mass balance for the ice cap to be zero, the mean annual velocities at all points around the equilibrium line would have to be double those measured. This ratio of mean annual to spring velocities would far exceed the seasonal variations generally observed on other polythermal Arctic glaciers, for example, on Hessbreen, Spitsbergen (Sund and Eiken, 2004), Storglaciaren, Sweden (Hooke and others, 1983), or Jakobshavn Isbræ, Greenland (Luckman and Murray, 2005). Kongsvegen (Melvold and Hagen, 1998) and Finsterwalderbreen (Nuttall and others, 1997) on Spitsbergen have both been observed to have summer surface velocities double those of winter at upper levels. However, this seasonal velocity increase translates into a mean-annual to spring flux rate ratio of 1.5 because of the number of months over which the velocities were measured.

Evidence in support of continuing increases in total mass balance of the ice cap comes from repeat-pass airborne laser altimetry surveys in 1996 and 2002 (Bamber and others, 2004), the surface elevations acquired in 1996 being those used as ground control for the interferometry in this study and shown in Figure 1. The results of the surveys indicated that, from 1996 to 2002, ice-surface elevations over central regions of the ice cap increased by an average of $0.5 \mathrm{ma}^{-1}$. Even allowing for the conversion from ice to water equivalent, this value is twice as large as the largest mean local mass balance calculated here.

Bamber and others (2004) concluded that the elevation increases $(\mathrm{d} h / \mathrm{d} t)$ detected by the laser altimetry surveys were not dynamic in origin but were due to increased accumulation rates. This conclusion was reached partly on the basis that the increases spanned several dynamically independent drainage basins. For example, there was no change in $\mathrm{d} h / \mathrm{d} t$ crossing from basin 21108 to 22203 (referred to as basins 3 and 17, respectively, in Bamber and others (2004)). Our study indicates that although these two basins surged some 55 years apart, their accumulation zones exhibit very similar mean local mass balances. The elevation increase detected by the altimetry survey appears to decrease markedly from basin 21108 to basins 21106 and 25204 , coinciding with the change from positive to negative mean local mass balances detected here. The measured $\mathrm{d} h / \mathrm{d} t$ 's mostly post-date the ice-core accumulation rate estimates, which showed no signs of temporal trend between 1963-86 and 1986-98 (Pinglot and others, 2001). Therefore, we propose that the extensive elevation increases detected by the laser altimetry survey may be the result of both ongoing basin dynamics and a recent increase in accumulation rate.

In interpreting any imbalance between balance and measured fluxes in terms of mass gain of the ice cap, it is important to note that a comparison is being made here between quantities that are representative of different timescales. The balance fluxes, being based on ice cores, are averaged over more than a decade and hence can be taken to represent current climate. The measured fluxes are only a contemporary snapshot but, for steady-flow glaciers, are a reflection of past climatic conditions because of the long dynamic response time of Arctic ice masses. An orderof-magnitude estimate of the response time for Austfonna, given by the ratio of the maximum ice thickness to the ablation rate at the terminus (Paterson, 1994), is 1000 years. Alternatively, relative response times of individual drainage basins can be inferred from the residence times, which were all in excess of 500 years.

It is also important to emphasize that this analysis deals only with the accumulation zone of Austfonna. In order for the mass balance of the ice cap to be interpreted in terms of its impact on global sea levels, ablation rates and calving fluxes must also be considered. It may be possible to use remote-sensing methods to estimate calving fluxes, but at present there is very little information available on ablation rates for Austfonna.

\section{CONCLUSIONS}

Although predictions and observations in the Arctic indicate that Svalbard's ice caps will be important indicators of climate change, mass-balance assessments of glaciers in Svalbard are very limited. This study aimed to compare measured and balance fluxes at the ELA on Austfonna, and showed that during the period 1994-96 the accumulation zone was in a state of positive mass balance. Measured surface velocities obtained using SRI combined with RES ice thicknesses gave an equilibrium-line annual flux of $(4.9 \pm 1.0) \times$ $10^{8} \mathrm{~m}^{3}$ w.e. $\mathrm{a}^{-1}$, equivalent to about half the total annual accumulation. The spatial distribution of local mass balance was revealed by separately analyzing each drainage basin. This analysis showed the positive mass balance to be contributed mainly by three glaciers known to be in surge recovery. The mean local mass balance within these basins is not inconsistent with elevation changes for 1996-2002 measured using repeat laser altimetry surveys, but indicates an underlying dynamic component to the changes.

\section{ACKNOWLEDGEMENTS}

The 1996 ERS SAR images were supplied by the European Space Agency under the VECTRA project AO108, coordinated by A. Shepherd. We are also grateful to T. Strozzi of Gamma Remote Sensing who made available the 1994 images, also acquired under VECTRA. Thanks are due to J. Bamber for the 1996 airborne laser altimetry data. S. Bevan was funded by UK Natural Environment Research Council PhD Studentship NER/S/A/2003/11395.

\section{REFERENCES}

Bamber, J.L. and A.J. Payne, eds. 2004. Mass balance of the cryosphere: observations and modelling of contemporary and future changes. Cambridge, Cambridge University Press. 
Bamber, J., W. Krabill, V. Raper and J. Dowdeswell. 2004. Anomalous recent growth of part of a large Arctic ice cap: Austfonna, Svalbard. Geophys. Res. Lett., 31(12), L12402. (10.1029/2004GL019667.)

Dowdeswell, J.A. 1986. Drainage-basin characteristics of Nordaustlandet ice caps, Svalbard. J. Glaciol., 32(110), 31-38.

Dowdeswell, J.A. and D.J. Drewry. 1989. The dynamics of Austfonna, Nordaustlandet, Svalbard: surface velocities, mass balance, and subglacial melt water. Ann. Glaciol., 12, 37-45.

Dowdeswell, J.A., D.J. Drewry, A.P.R. Cooper, M.R. Gorman, O. Liestøl and O. Orheim. 1986. Digital mapping of the Nordaustlandet ice caps from airborne geophysical investigations. Ann. Glaciol., 8, 51-58.

Dowdeswell, J.A., B. Unwin, A.M. Nuttall and D.J. Wingham. 1999. Velocity structure, flow instability and mass flux on a large Arctic ice cap from satellite radar interferometry. Earth Planet. Sci. Lett., 167(3-4), 131-140.

Drewry, D.J. and O. Liestøl. 1985. Glaciological investigations of surging ice caps in Nordaustlandet, Svalbard, 1983. Polar Rec., 22(139), 359-378.

Førland, E.J. and I. Hanssen-Bauer. 2000. Increased precipitation in the Norwegian Arctic: true or false? Climatic Change, 46(4), 485-509.

Hagen, J.O. and O. Liestøl. 1990. Long-term glacier mass-balance investigations in Svalbard, 1950-88. Ann. Glaciol., 14, 102-106.

Hagen, J.O., O. Liestøl, E. Roland, and T. Jørgensen. 1993. Glacier atlas of Svalbard and Jan Mayen. Nor. Polarinst. Medd. 129.

Hagen, J.O., K. Melvold, F. Pinglot and J.A. Dowdeswell. 2003. On the net mass balance of the glaciers and ice caps in Svalbard, Norwegian Arctic. Arct. Antarct. Alp. Res., 35(2), 264-270.

Hooke, R.LeB., J. Brzozowski and C. Bronge. 1983. Seasonal variations in surface velocity, Storglaciären, Sweden. Geogr. Ann., 65A(3-4), 263-277.

Jiskoot, H., T. Murray and P. Boyle. 2000. Controls on the distribution of surge-type glaciers in Svalbard. J. Glaciol., 46(154), 412-422.

Kwok, R. and M.A. Fahnestock. 1996. Ice sheet motion and topography from radar interferometry. IEEE Trans. Geosci. Remote Sens., 34(1), 189-200.
Lefauconnier, B., J.O. Hagen, J.F. Pinglot and M. Pourchet. 1994. Mass-balance estimates on the glacier complex Kongsvegen and Sveabreen, Spitsbergen, Svalbard, using radioactive layers. J. Glaciol., 40(135), 368-376.

Luckman, A. and T. Murray. 2005. Seasonal variations in velocity before retreat of Jakobshavn Isbrae, Greenland. Geophys. Res. Lett., 32, L08501. (10.1029/2005GL022519.)

McCarthy, J.J., O.F. Canziani, N.A. Leary, D.J. Dokken and K.S. White. 2001. Climate change 2001: impacts, adaptation, and vulnerability. Contribution of Working Group II to the Third Assessment Report of the Intergovernmental Panel on Climate Change. Cambridge, etc., Cambridge University Press.

Melvold, K. and J.O. Hagen. 1998. Evolution of a surge-type glacier in its quiescent phase: Kongsvegen, Spitsbergen, 1964-95. J. Glaciol., 44(147), 394-404.

Nuttall, A.M., J.O. Hagen and J. Dowdeswell. 1997. Quiescentphase changes in velocity and geometry of Finsterwalderbreen, a surge-type glacier in Svalbard. Ann. Glaciol., 24, 249-254.

Paterson, W.S.B. 1994. The physics of glaciers. Third edition. Oxford, etc., Elsevier.

Pinglot, J.F., J.O. Hagen, K. Melvold, T. Eiken and C. Vincent. 2001. A mean net accumulation pattern derived from radioactive layers and radar soundings on Austfonna, Nordaustlandet, Svalbard. J. Glaciol., 47(159), 555-566.

Pohjola, V.A. and 6 others. 2002. Reconstruction of three centuries of annual accumulation rates based on the record of stable isotopes of water from Lomonosovfonna, Svalbard. Ann. Glaciol., 35, 57-62.

Rignot, E., K. Echelmeyer and W. Krabill. 2001. Penetration depth of interferometric synthetic-aperture radar signals in snow and ice. Geophys. Res. Lett., 28(18), 3501-3504.

Sund, M. and T. Eiken. 2004. Quiescent phase dynamics and surge history of a polythermal glacier: Hessbreen, Svalbard. J. Glaciol., 50(171), 547-564.

Unwin, B.V. 1998. Arctic ice cap velocity variations revealed using ERS SAR interferometry. (PhD thesis, University College London.) 